\title{
Fish Ladder Weir Modifications to Minimize Escapement
}

\section{Eric Krebs', Dylan A. Gravenhof ${ }^{2}$, Joshua M. A. Caasi', Robert P. Hanten ${ }^{2}$, Nathan Huysman', Jill M. Voorhees ${ }^{1}$, Michael E. Barnes ${ }^{1 *}$}

\author{
${ }^{1}$ South Dakota Department of Game, Fish and Parks, McNenny State Fish Hatchery, Spearfish, South Dakota, USA \\ ${ }^{2}$ South Dakota Department of Game, Fish and Parks, Missouri River Fisheries Center, Fort Pierre, South Dakota, USA \\ Email: *mike.barnes@state.sd.us
}

How to cite this paper: Krebs, E., Gravenhof, D.A., Caasi, J.M.A., Hanten, R.P., Huysman, N., Voorhees, J.M. and Barnes, M.E. (2021) Fish Ladder Weir Modifications to Minimize Escapement. Engineering, 13, 173-183.

https://doi.org/10.4236/eng.2021.134013

Received: March 13, 2021

Accepted: April 10, 2021

Published: April 13, 2021

Copyright () 2021 by author(s) and Scientific Research Publishing Inc. This work is licensed under the Creative Commons Attribution International License (CC BY 4.0).

http://creativecommons.org/licenses/by/4.0/

\begin{abstract}
A fish ladder, weir, and raceway at Whitlock Spawning Station are used to capture and retain feral fall Chinook salmon (Oncorhynchus tshawytscha) for spawning from Lake Oahe, South Dakota. Nearly $40 \%$ of the salmon ascending the fish ladder have been documented to escape from the holding raceway by descending the ladder. This manuscript describes modifications to the weir that eliminated nearly all escapements, except for an inconsequential number of small non-spawning fish. The modified design using the existing structure incorporated free-swinging, spaced steel bars with a back-stop to create a one-way gate. The modified gate does not require springs, hydraulics, or electrical power. It is relatively simple to construct and requires minimal maintenance.
\end{abstract}

\section{Keywords}

Fish Ladder, Chinook Salmon, Weir, Spawning

\section{Introduction}

The capture of wild salmon to provide gametes for artificial propagation is a common occurrence [1]. Fish for spawning can be obtained by a number of different methods, including traps, weirs, and fish ladders [2] [3] [4]. Although these capture devices may allow the unhindered in-and-out movement of fish, barriers are frequently incorporated into the structures to prevent fish escapement [4] [5] [6]. For example, a weir can be added to a fish ladder to discourage the downward movement of fish initially ascending the ladder.

Whitlock Spawning Station on Lake Oahe, South Dakota, USA, uses a fish ladder, weir, and raceway to capture and hold feral landlocked Chinook salmon 
(Oncorhynchus tshawytscha) for spawning. Lake Oahe is 150,000 ha mainstem Missouri River reservoir in North and South Dakota, USA. The Lake Oahe population of fall Chinook salmon is sustained entirely by hatchery stocking [7]; there is no natural reproduction [8]. The number of salmon spawned annually at the station is highly variable but typically is well below that required to maintain the population at desired levels [9]. In addition, the success of artificial propagation in this population is often poor [10] [11].

The station is located on the shore of Lake Oahe, approximately $32 \mathrm{~km}$ west of Gettysburg, South Dakota, USA (Figure 1). Submersible pumps supply lake water to the raceways and fish ladder. The ladder consists of a series of V-shaped concrete sections forming the channel, with metal plates forming pools. The ladder extends from the station into the reservoir (Figure 2). At the top of the ladder is an open weir that directs the fish into a $13.7 \mathrm{~m}$ long, $2.4 \mathrm{~m}$ wide, and $1.2 \mathrm{~m}$ deep holding raceway (Figure 3 ). The station also has additional raceways and an enclosed building for spawning [12].

Escapement of salmon broodstock from the station was erroneously assumed to be negligible for the first 33 years of operation. However, in 2017, a mark-recapture study revealed that nearly $40 \%$ of the salmon that ascended the fish ladder subsequently descended the ladder through the open weir and escaped from the station prior to spawning [13]. Re-engineering of the weir at the top of the fish ladder was recommended to increase the number of salmon retained at the station for spawning [13].

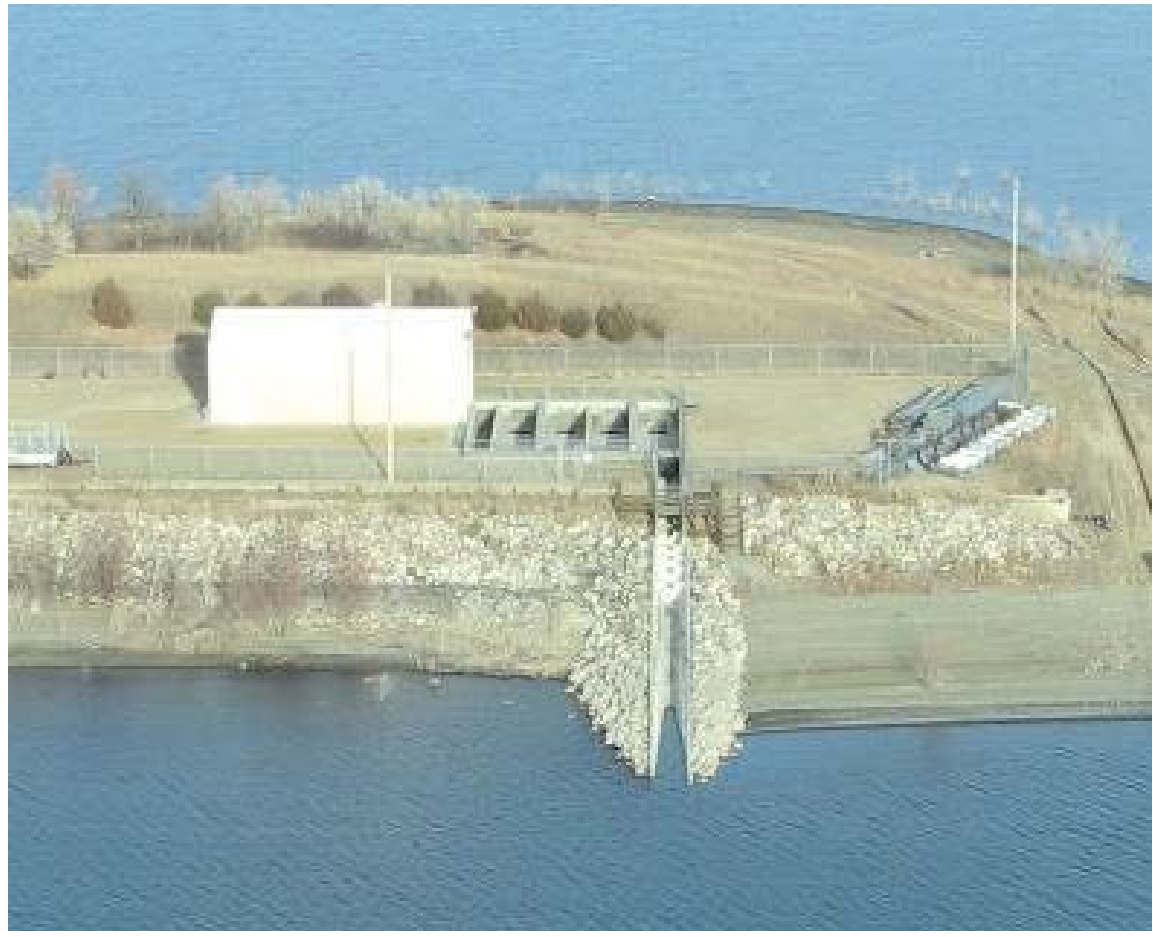

Figure 1. Whitlock Spawning Station on Lake Oahe, South Dakota, USA. Note the building, catch raceways, and fish ladder (this image was taken when the station was not in operation, so no water is in the raceways or ladder). 


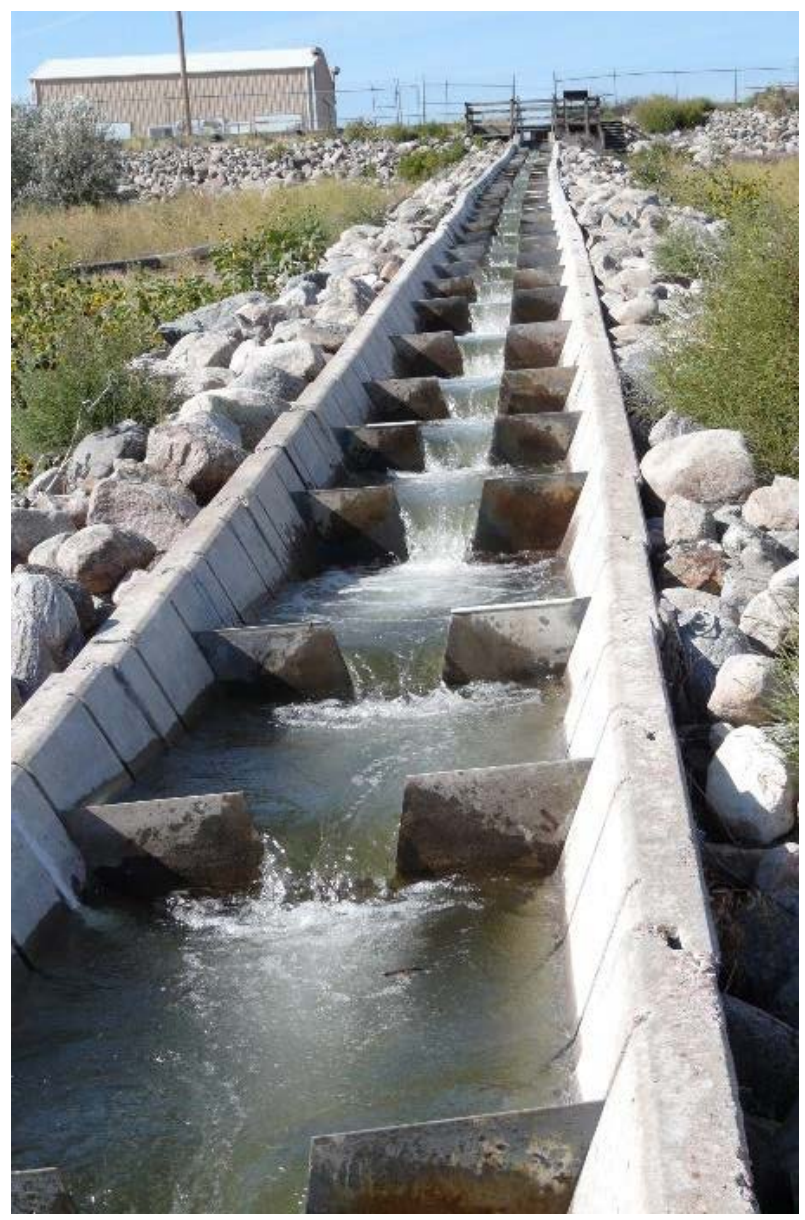

Figure 2. The fish ladder in operation at Whitlock Spawning Station on Lake Oahe, South Dakota, USA.

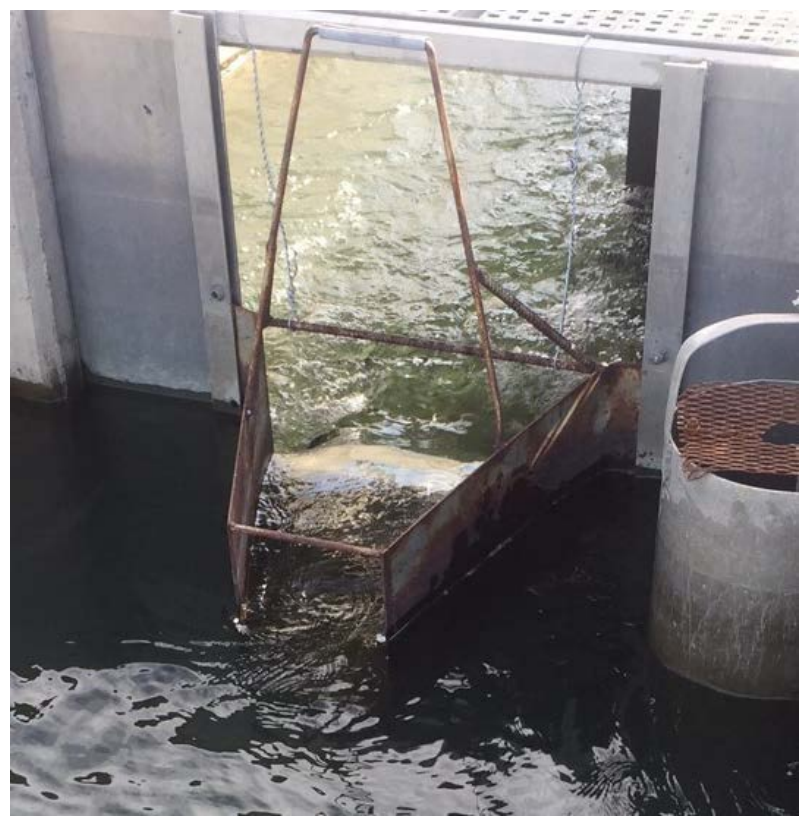

Figure 3. The open weir at the top of the fish ladder at Whitlock Spawning Station on Lake Oahe, South Dakota, USA. 


\section{Design}

The existing weir at the top of the ladder was modified to minimize escapement. The pre-modified weir is illustrated in Figures 4-7. It consists of two sides of $3.18-\mathrm{mm}$ thick mild steel plates $(52.59 \mathrm{~cm}$ long and $38.10 \mathrm{~cm}$ high) welded to an expanded steel mesh floor. The side plates are bent to a $106.8^{\circ}$ angle to form an 8.14-cm long flange on either side. These flanges slide into corresponding slots at the top of the ladder to anchor the weir into place. The side plates are angled toward each other so that the opening between them narrows from $51.03 \mathrm{~cm}$ at the top of the ladder to $20.83 \mathrm{~cm}$ at the end of the weir next to the catch raceway. Two $9.53-\mathrm{mm}$ mild steel round rods (30.18 and $51.03 \mathrm{~cm}$ long) are welded to the top of the structure to provide stability. A handle constructed of 9.53-mm steel round rods is also welded to the top of the weir to aid in insertion and removal.

This existing structure was modified to allow for only one-way movement of the salmon. An overview of the modified structure is illustrated in Figure 8. The design added free-swinging, equally-spaced steel bars to the existing weir to create a one-way gate (Figure 9).

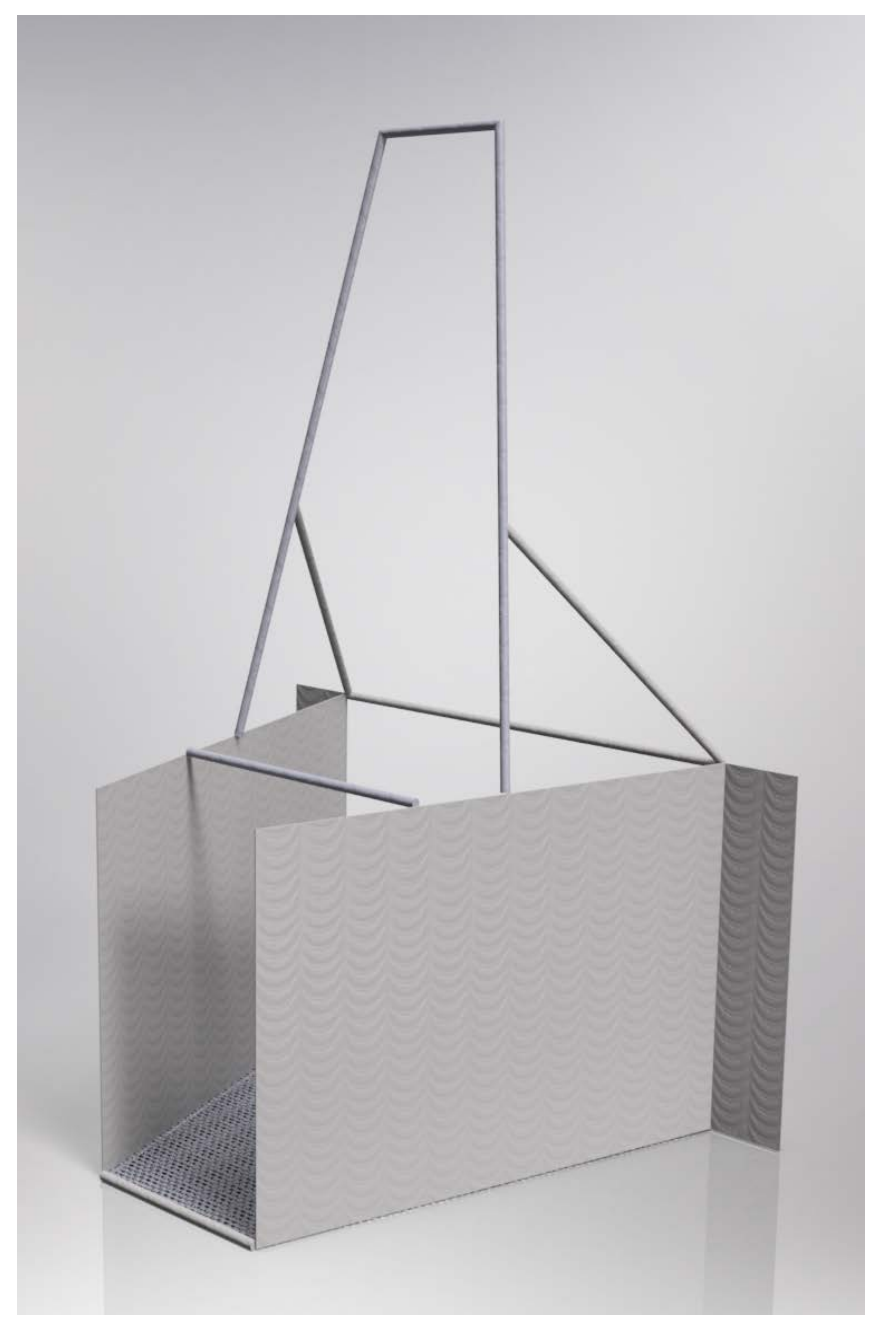

Figure 4. A close-up of the weir removed from the fish ladder. 


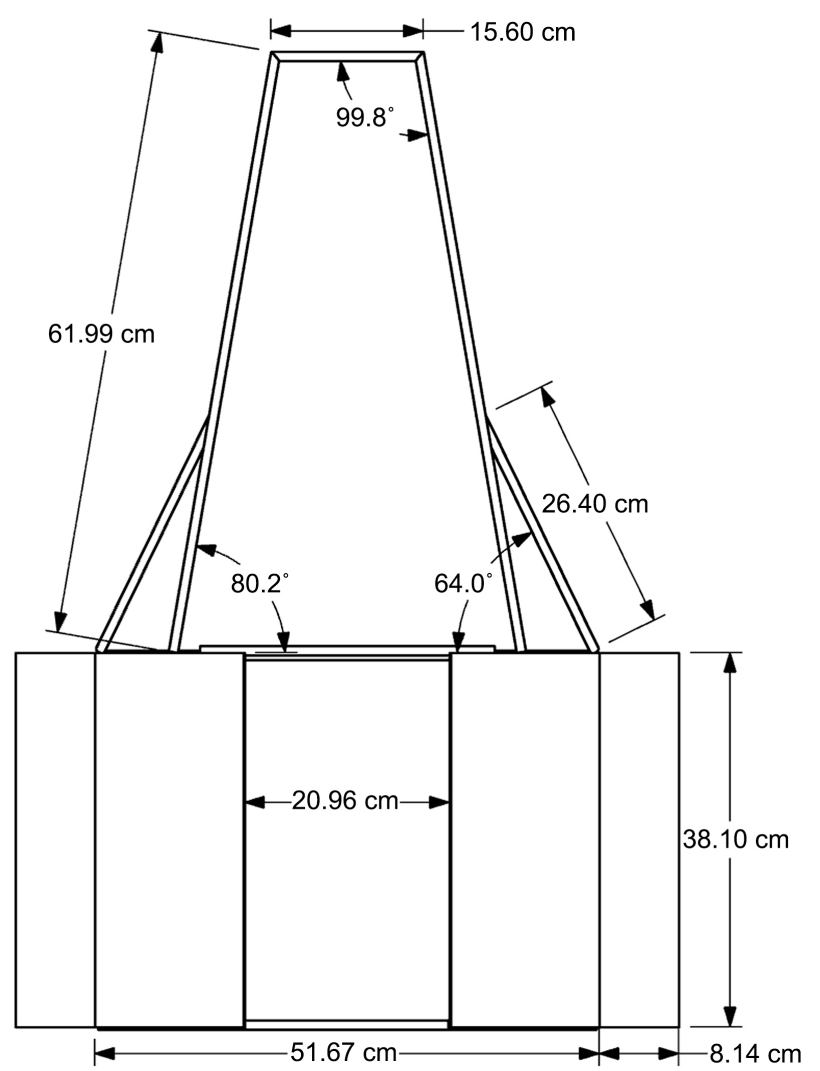

Figure 5. A front view schematic of the weir.

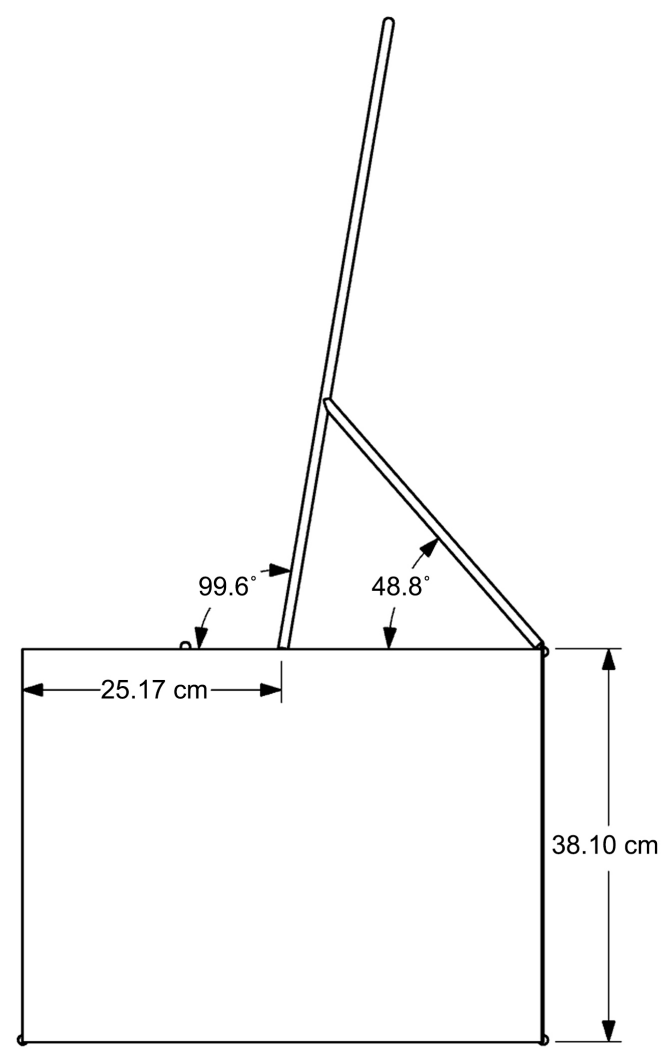

Figure 6. A side view schematic of the weir. 


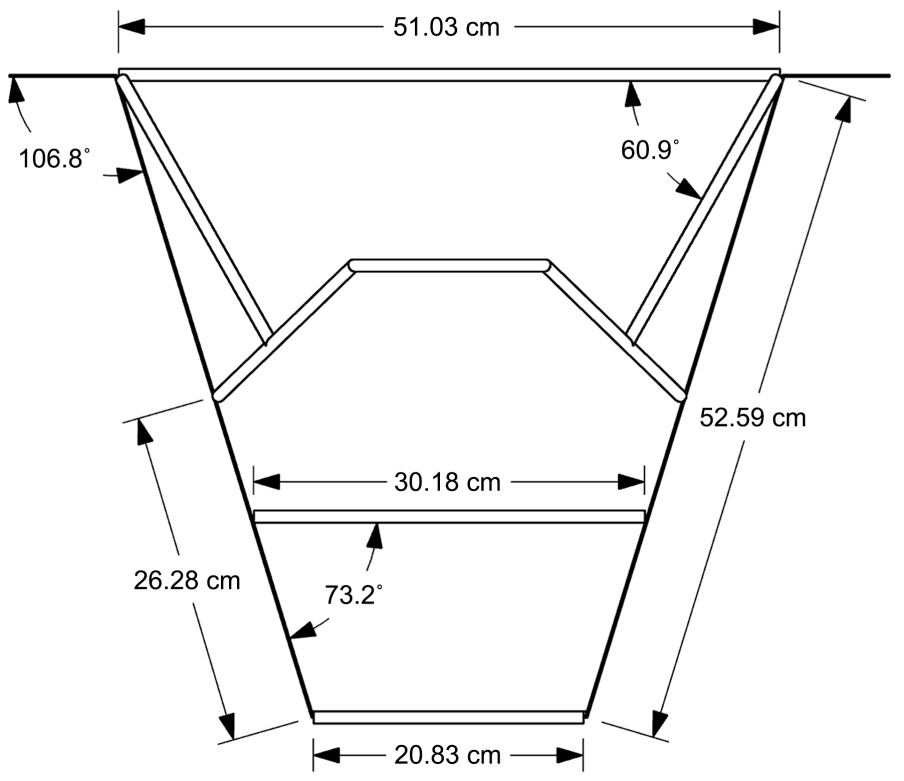

Figure 7. A top view schematic of the weir.

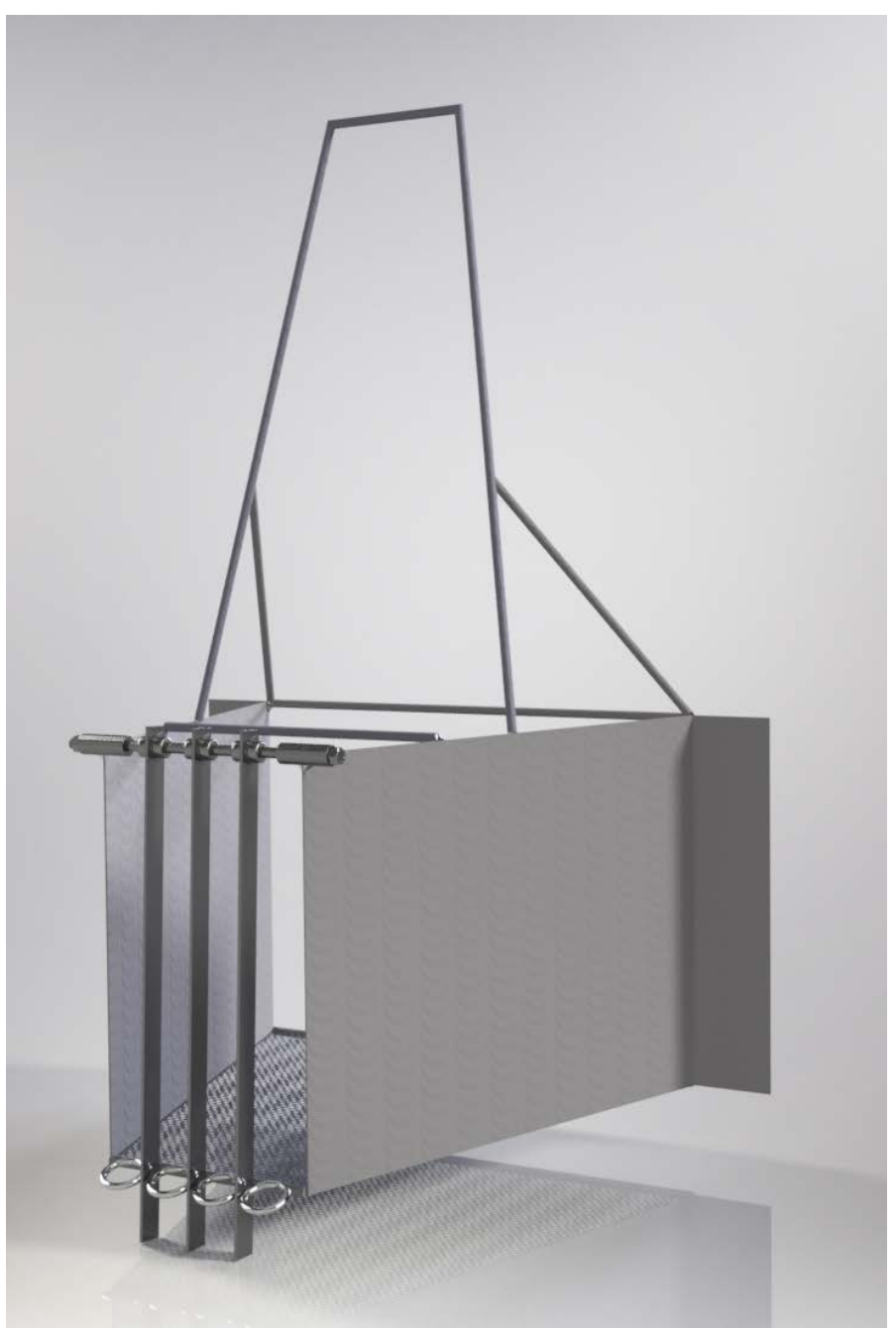

Figure 8. The weir with the modifications to prevent fish escapement. 


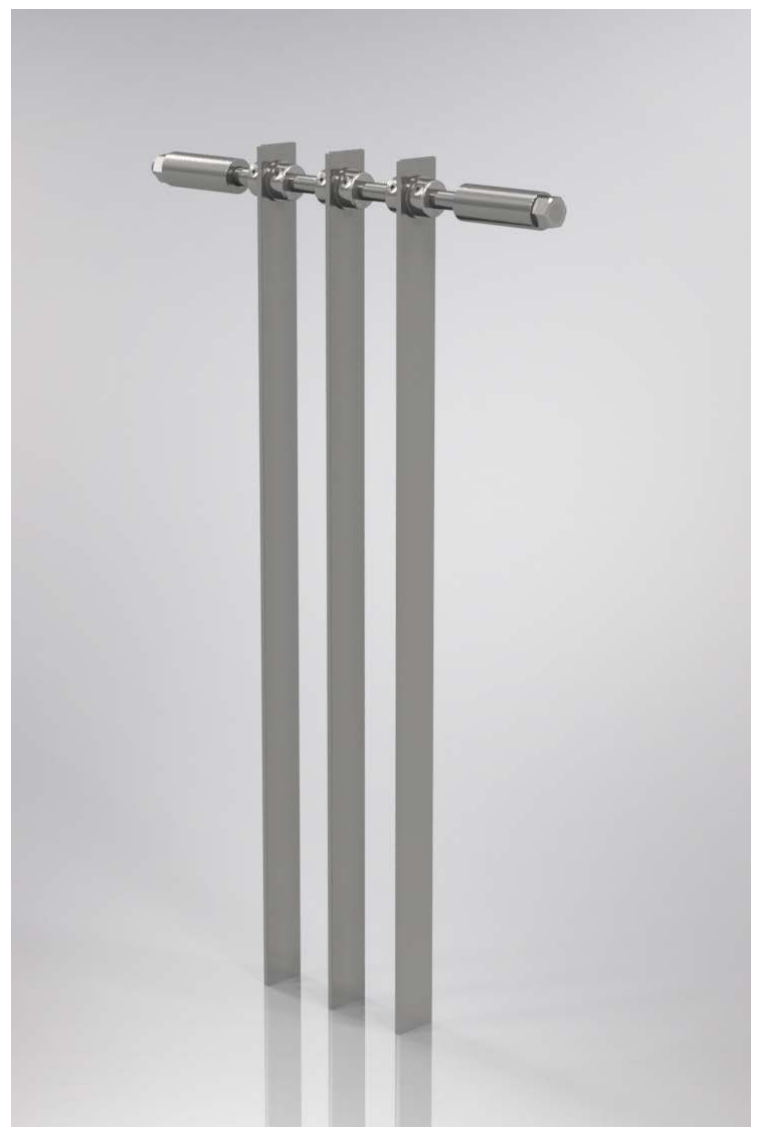

Figure 9. A close-up of the one-way swinging gate installed on the weir to prevent salmon escapement.

To create the freely-rotating component, two sections of galvanized round steel tube (5.03 cm long, $2.53 \mathrm{~cm}$ O.D., $1.28 \mathrm{~cm} \mathrm{I.D.)} \mathrm{were} \mathrm{used.} \mathrm{Each} \mathrm{piece} \mathrm{of}$ tube was welded horizontally into $1.27-\mathrm{cm}$ notches cut at top front edge of the narrow (catch raceway) side of the weir, with approximately $2.44 \mathrm{~cm}$ extending past the sides. A stainless-steel bolt (1.27 cm O.D., $28.58 \mathrm{~cm}$ long; $19.05 \mathrm{~mm}$ hex head), was inserted to span the entire length of the tubes. The bolt was threaded on one end (3.81 cm of threading at 1.95 threads $/ \mathrm{mm}$ ). A stainless steel, nylon infused, locking nut was used to secure the bolt. The nut was tightened to eliminate nearly all horizontal movement of the bolt, yet still allow for rotation of the bolt inside the tubes.

Three galvanized mild steel bars ( $45.9 \mathrm{~cm}$ long, $2.54 \mathrm{~cm}$ wide, $3.18 \mathrm{~mm}$ thick) were vertically suspended from the bolt via predrilled $1.28-\mathrm{cm}$ diameter holes at the upper end of the bars. The bars were spaced on the bolt at approximately 4.7 $\mathrm{cm}$. (Figure 10). The bars were held in place with stainless steel shaft collar stops containing set screws and secured to either side of each bar with a stainless-steel washer between the bar and collar (Figure 11). These collars and washers were pressed against the bars and the set screws were tightened enough to limit lateral movement while still allowing each bar to rotate or swing easily and independently on the bolt. The washers were able to rotate as well, to prevent fine debris 
from accumulating and potentially impairing bar rotation. Approximately 5.08 $\mathrm{cm}$ of each bar extends below the bottom of the weir, limiting the rotation to allow for only one-way fish passage. At the bottom edge of the weir, four mild steel rings (3.81 cm O.D., $5.70 \mathrm{~mm}$ thick) are evenly spaced and welded in place (Figure 12). These rings protrude from the edge $3.34 \mathrm{~cm}$ to provide lateral stability to the bars. In the down position, the bars rest between the rings with enough space to easily rotate but cannot be easily moved or flexed laterally to further preclude escapement. The round shape of the rings allows the bars to smoothly fall into the desired position and also prevent fish injury.

The rotating bars allow salmon ascending the ladder to push the bars out of the way and enter the catch raceway. The bars rotate back to their original resting position by their own weight after salmon passage, preventing any escapement of salmon down the ladder. The independent movement of the bars accommodates varying fish sizes and allows for more than one fish to pass through the weir at a time.

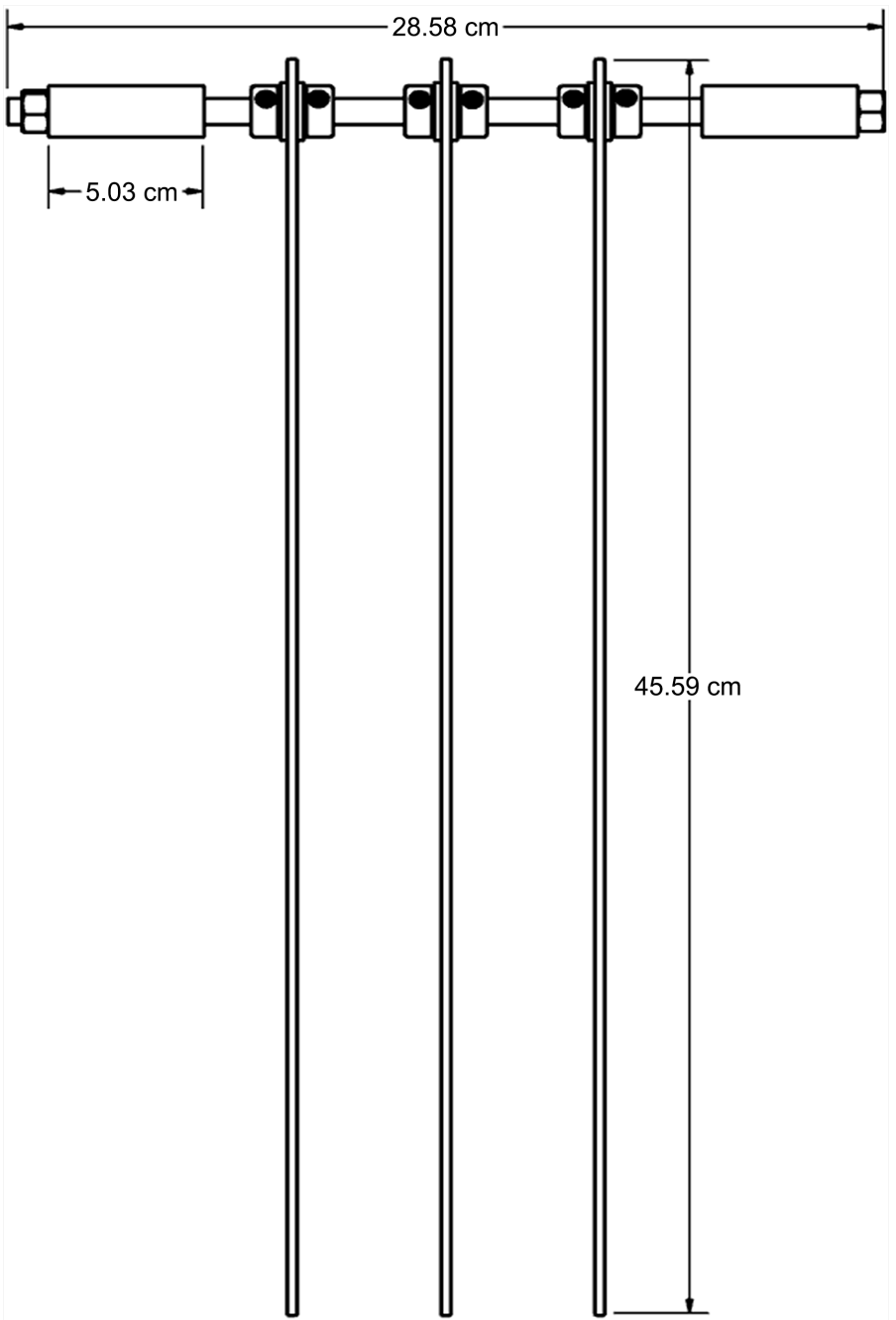

Figure 10. A schematic of the one-way swinging gate installed on the weir to prevent salmon escapement. 


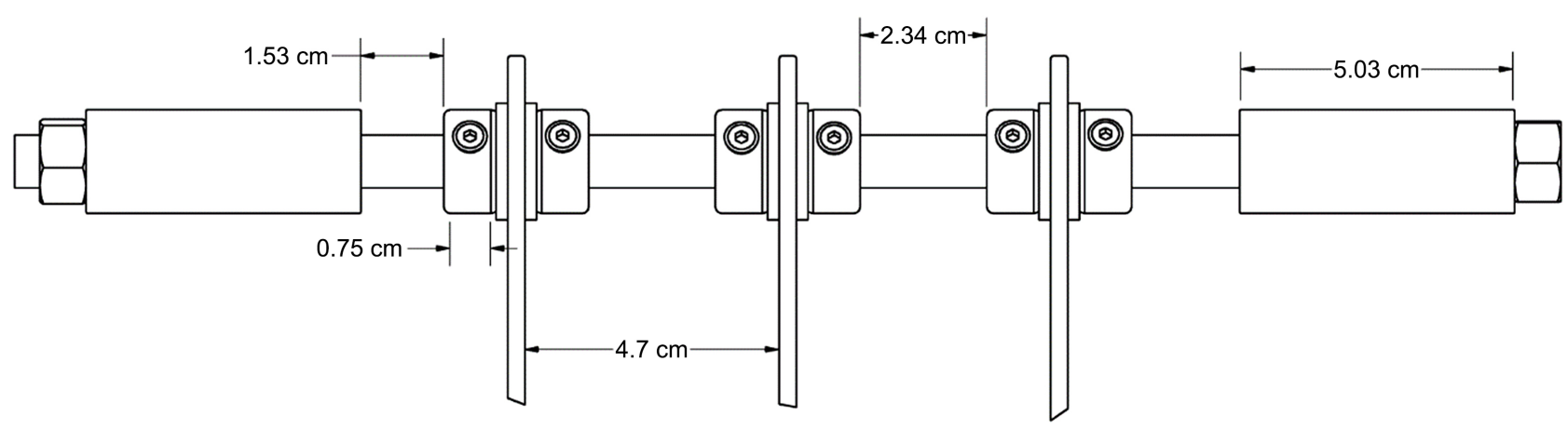

Figure 11. Schematic of the rotational component of the modifications to the weir.

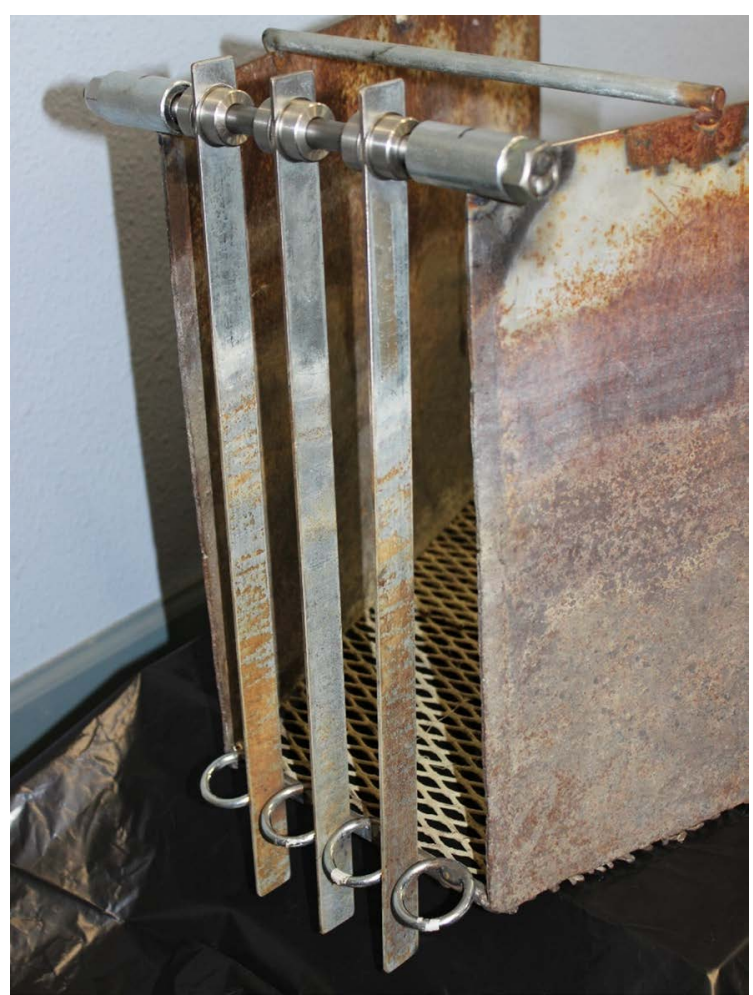

Figure 12. The modified weir after operation during one spawning season.

\section{Evaluation}

The modified weir was used during the Chinook salmon spawning season in the fall of 2019. A night vision capable video camera (Model LBV2531W, Lorex Technology Inc., Markham, Ontario, Canada) was used to monitor the weir during the spawning period. Video footage from two periods was used to estimate escapement rates. Each period began after dewatering of the holding raceway and lasted until the next dewatering event to allow for physical confirmation of the video footage. The first period lasted 49 hours, during which 48 fish passed through the weir into the holding raceway. Two fish were observed passing back through the weir (descending the fish ladder). However, both of these fish were very small and would not have been spawned. The second period en- 
compassed 142 hours, during which 67 salmon passed through the weir into the holding raceway. Only one small fish was observed swimming back through the weir. Thus, over 191 hours, a total of 115 fish ascended the ladder and passed through the weir to the holding raceway, with only three fish (2.6\%) escaping. And the three fish were all small and would not have contributed to the overall spawning effort. With regard to egg collection, the modified weir reduced escapement to zero.

The potential effect that the weir may have had on fish movement from the ladder into the holding raceway is unknown. However, it is unlikely that the bars impeded fish from entering the holding raceway, given the relatively large number of salmon that were spawned after placement of the modified weir. Further evaluation in this regard would be beneficial.

\section{Conclusion}

Modifying the existing weir was advantageous in several ways. Fish escapement was significantly reduced and in relation to spawning salmon completely eliminated. In addition, the labor requirements and the cost of materials were substantially reduced in comparison to constructing an entirely new structure. The simplicity of the design, using only gravity and minimal moving parts, has thus far been maintenance free. In addition, little long-term maintenance is expected, in comparison to other structures using springs or other more complex mechanisms to create one-way passage [14].

\section{Acknowledgements}

We thank Mike Smith, Mark Fincel, Cameron Goble, and the spawning crew at Whitlock Spawning Station for their assistance with this project.

\section{Conflicts of Interest}

The authors declare no conflicts of interest regarding the publication of this paper.

\section{References}

[1] McIntyre, J.D. (1991) Pacific Salmon Culture for Stocking. In: Stickney, R.R., Ed., Culture of Salmonid Fishes, CRC Press, Boca Raton, Florida, 58-70.

[2] Piper, R.G., McElwain, I.B., Orme, L.E., McCraren, J.P., Fowler, L.G. and Leonard, J.R. (1982) Fish Hatchery Management. United States Fish and Wildlife Service, Washington D.C.

[3] Brannon, E.L. (1991) Rainbow Trout Culture. In: Stickney, R.R., Ed., Culture of Salmonid Fishes, CRC Press, Boca Raton, Florida, 22-55.

[4] Schroeder, R.K. (1996) A Review of Capture Techniques for Adult Anadromous Salmonids. Oregon Department of Fish and Game, Portland, Oregon.

[5] Leitritz, E. and Lewis, R.C. (1980) Trout and Salmon Culture (Hatchery Methods). California Fish Bulletin 164. Division of Agricultural Sciences, University of California, Sacramento, California. 
[6] Fisheries Rehabilitation, Enhancement and Development Division (1983). Fish Culture Manual. Alaska Department of Fish and Game, Juneau, Alaska.

[7] Lott, J., Marrone, G.M. and Stout, D.A. (1997) Influence of Size-and-Date at Stocking, Imprinting Attempts and Growth on Initial Survival, Homing Ability, Maturation Patterns and Angler Harvest of Chinook Salmon in Lake Oahe, South Dakota. South Dakota Department of Game, Fish and Parks, Special Report 97-20. Pierre, South Dakota.

[8] Marrone, G.M. and Stout, D.A. (1997) 1997 Whitlock Bay Spawning Station Annual Report. South Dakota Department of Game, Fish and Parks, Annual Report 97-19. Pierre, South Dakota.

[9] Maahs, B.C., Meyer, H.A., Huysman, N.D., Voorhees, J.M. and Barnes, M.E. (2018) Mortality of Landlocked Fall Chinook Salmon Broodstock After Electrofishing or Ascending a Fish Ladder. Jacobs Journal of Aquaculture and Research, 3, 19.

[10] Barnes, M.E., Hanten, R.P., Cordes, R.J., Sayler, W.A. and Carreiro, J. (2000) Reproductive Performance of Inland Fall Chinook Salmon. North American Journal of Aquaculture, 62, 203-211. https://doi.org/10.1577/1548-8454(2000)062<0203:RPOIFC>2.3.CO;2

[11] Young, K.L., Barnes, M.E. and Kientz, J.L. (2016) Reproductive Characteristics of Landlocked Fall Chinook Salmon from Lake Oahe, South Dakota. Prairie Naturalist, 48, 79-86.

[12] Hanten, R. (2011) 2010 Whitlock Bay Spawning Station Report. South Dakota Department of Game, Fish and Parks, Annual Report No. 11-02. Pierre, South Dakota.

[13] Gravenhof, D.A., Hanten, R.P. and Barnes, M.E. (2020) Escapement of Broodstock Chinook Salmon from Whitlocks Spawning Station, Lake Oahe, South Dakota. $A q$ uatic Science and Technology, 9, 18-24. https://doi.org/10.5296/ast.v9i1.17330

[14] Barrows, M.G., Hudson, J.M. and Hauser, K. (2019) Clackamas River Bull Trout Reintroduction Project, 2018 Annual Report. United States Fish and Wildlife Service. Columbia River Fish and Wildlife Conservation Office, Vancouver, Washington. 